\title{
The Assessment of Investment Preferences in Exemplary Tourism Regions (The Case of Kashan Township, Iran)
}

\author{
Omid Mobaraki (Corresponding Author) \\ Department of Geography and Urban Planning, University of Maraghe, Iran \\ Tel: 98-091-4922-5609Ｅ-mail: omidmobaraki@gmail.com
}

\begin{abstract}
Rahim Sarvar
Department of Geography in Islamic Azad University- Shahre Rey Branch

Tel: 98-091-2238-9990Ｅ-mail: sarvarh83@gmail.com
\end{abstract}

\author{
Mahdi Abdollahzadeh \\ MA in Geography and Tourism Planning
}

Tel: 98-091-4363-8353Ｅ-mail: mahdi3249@yahoo.com

Received: January 14, 2014 Accepted: January 28, 2014

doi:10.5296/emsd.v3i1.5177～URL: http://dx.doi.org/10.5296/emsd.v3i1.5177

\begin{abstract}
Nowadays many countries in the world have appreciated the broad dimensions of tourism industry in terms of production, employment and revenue production. From a couple of decades ago these countries have been developing this industry to a great extent. Iran is one of the countries that -due to having natural, historical and cultural potentials has always been noticed by tourists from all over the world; and this provides appropriate conditions to utilize and develop tourism infrastructures. According to article 9 of establishing act of cultural heritage, artifacts and tourism organization, in order to attract domestic and foreign investors and to establish infrastructural tourism installations and providing tourists with proper services, the government can let the nongovernmental applicant establish exemplary tourism areas in appropriate regions of the country and tourism poles with an emphasis on less developed regions. In this research, using SWOT strategic model, we tried to identify
\end{abstract}


strengths and weaknesses of exemplary tourism areas in Kashan and then we assessed and prioritized investment in the exemplary regions of this city proportionate to the strengths and weaknesses of them using the analytical and hierarchical process (AHP). And finally we have offered some approaches to further develop tourism in these regions. The results of the research indicated that among the selected and approved exemplary regions in Kahsan township, Qamsar region and Niyasar region had the most ranking for tourism development investments with the ranking coefficients of 1.7384 and 1.7157 respectively.

Keywords: tourism regions, SWOT, AHP, Kashan Township.

\section{Introduction}

Economical development in any country requires investment indifferent sections and activities. Without investment in infrastructural and ultra structural projects, one cannot expect developments in employment, production and economical well-being. To achieve this goal, nowadays many countries in the world have a great tendency towards attracting foreign investments. Investment in tourism infrastructures and using the potentials in the region to attract tourists is an appropriate way to achieve this goal (Ebrahimzade and Aqasizade, 2010), because tourism and passing leisure time in a new way, are consequent and simultaneous phenomena and an inherent part of the industrial society and an important chain in its reproduction (Momeni, 2005). It is also a great part of the global economy (Scott and Mc Boyle, 2004, 105) to the extent that in today's tourism in the world, it is an income resource and one of the effective factors in cultural transactions among countries. As the broadest service industry in the world it is of great importance (Fannie and Mohammadnejhad, 2010). According to the statistics provided by World Tourism Organization (WTO) the number of tourists all over the world was over 701 million people and from this tourism flow, an amount of over 475 million dollars has entered directly to the economical cycle of the world. This amount was 922 million tourists and the income thereof was 944 billion dollars in 2008 (Fanni and Mohammadnejhad, 2010). In order to gain revenues from this method, every country must have two important characteristics: firstly, having the potential factors to attract tourists (resources and attraction), and secondly, the capacity to provide services and making tourism production (Khatayi, et al, 2008).

Resources and attraction are the main pivots of tourism in the world. Examining and identifying these resources and attractions is a part of basic studies in any tourism planning and design. Following the scientific and professional bases and considering the principles experienced in this industry can increase efficiency and decrease performance errors. Thus, in achieving the goals determined in the document of the 20-year Prospect of the Country (with an emphasis on entering 20 million tourists every year) and the Fifth Plan of Development, the assistant office of investment in the Organization of Cultural Heritage, Artifacts and Tourism has determined the exemplary tourism regions. In performing these plans, 7 exemplary regions have been determined in order to do domestic and foreign investments in Kashan Township. In this research we have tried to assess the strengths and weaknesses of these regions regarding tourism and have prioritized them for domestic and foreign investments using SWOT strategic model and the analytical hierarchical process. 


\section{The Study Area}

Kashan Township with a population of around 400000 people and a breadth of 2100 hectares is located at $51^{\circ} 27$ east and $33^{\circ}$ and 59 northern latitude. It is one of the most important cities of Isfahan province and has a great part of tourism attraction and potentials of this province. The historical background and its appropriate situation are some of the factors that have been effective in developing tourism potentials of this city. Kashan Township with 430 tourism attractions has $20.4 \%$ of attractions of Isfahan province. It is the second place after Isfahan city (the comprehensive tourism project of Isfahan province, 2010). Regarding the situation of this city and along with achieving the goals of the document of the 20-year prospect, Kashan has been selected and approved of as an exemplary tourism region. Table 1 includes the general characteristics of these regions.

\section{Materials and Procedures}

Regarding the factors under investigation and the nature of the topic, the approach dominating this research is descriptive-analytical. Considering the goals, this research is practical. In research literature, documentary, library and field methods have been used in order to collect information. In order to analyze data, SWOT model and AHP model and Expert, Choice and Excel software's have been used. First we have examined strengths and weaknesses of exemplary tourism regions in Kashan using SWOT strategic model and then using AHP process, we have assessed and prioritized these factors so as to determine prior regions for investment.

\subsection{SWOT Model}

SWOT is an analytical and strategic planning tool which is often used in corporate planning approach. The logic of this approach is that an affective procedure must maximize the strengths and opportunities of the system and minimize the weaknesses and threats. If applied properly, this logic will yield fruitful results for selecting and designing an effective approach (Hekmatnia and Mousavi, 2006). In order to perform SWOT method successfully, it is essential to have a proper knowledge of current conditions and dominating procedures. SWOT analysis has two main factors:

Internal factors (IFAS): that is described by the strengths and weaknesses in the current conditions:

Strengths: beautiful landscape, investment grounds for tourism, quiet and desirable environment, people's hospitability helps to use the opportunities and fight the threats.

Weaknesses: internal conditions or any internal deficiency which endangers the competitive situation of a region or reduces the possibility of using the opportunities. The table of the summary of the analysis of internal functions is a method of organizing internal factors and classifying them in a dichotomy of strengths and weaknesses (Hekmatnia, 2006). 


\section{Ml Macrothink}

Environmental Management and Sustainable Development

ISSN 2164-7682

2014, Vol. 3, No. 1

Table 1. The matrix table of internal factors effective in prioritizing exemplary tourism regions

\begin{tabular}{|c|c|c|}
\hline Variables & Strengths & Weaknesses \\
\hline Economical & $\begin{array}{l}\text { Appropriateness of the regions for tourism } \\
\text { investment and planning in order to utilize natural } \\
\text { and human resources and introducing them as } \\
\text { important tourism poles }\end{array}$ & $\begin{array}{l}\text { Reluctance of the people in exemplary } \\
\text { regions so as to invest in tourism segments in } \\
\text { order to get acquainted with this industry }\end{array}$ \\
\hline $\begin{array}{l}\text { Social and } \\
\text { cultural }\end{array}$ & $\begin{array}{l}\text { - high awareness, collaboration and } \\
\text { participation among the people of these } \\
\text { regions } \\
\text { - local artifacts } \\
\text { - } \text { social security required in exemplary } \\
\text { tourism regions } \\
\text { - hospitability of the local people of the } \\
\text { exemplary regions }\end{array}$ & $\begin{array}{l}\text { - } \\
\text { inappropriateness of residential and } \\
\text { welfare installations and facilities } \\
\text { inappropriate distribution of tourists } \\
\text { in different seasons of the year }\end{array}$ \\
\hline Ecological & 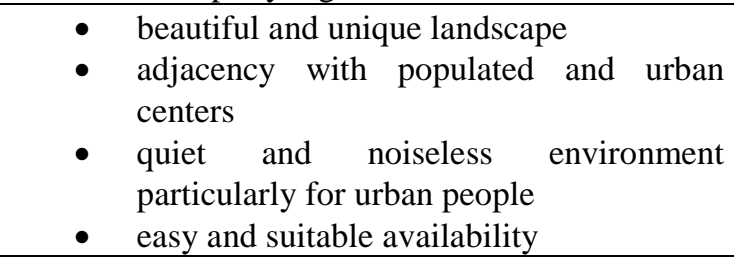 & $\begin{array}{l}\text { - inappropriateness of environmental } \\
\text { and corporal infrastructures } \\
\text { - inappropriateness of entertainment } \\
\text { installations and facilities } \\
\text { - the exemplary tourism regions' } \\
\text { being unknown }\end{array}$ \\
\hline $\begin{array}{l}\text { Organizationa } \\
1\end{array}$ & $\begin{array}{l}\text { The authorities' belief in job development by } \\
\text { means of developing tourism as one of the most } \\
\text { important approaches to develop less-developed } \\
\text { regions }\end{array}$ & 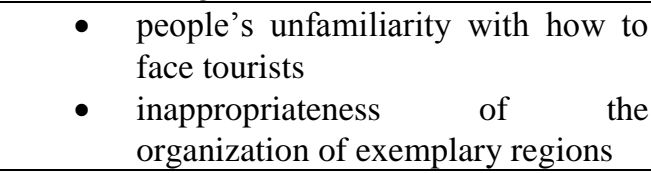 \\
\hline
\end{tabular}

Source: writers Studies

The Table 1 shows internal factors affecting tourism priority areas, and has been studied the strengths and weaknesses of economic variables, social, cultural, ecological and institutional systems.

a) External factors (EFAS): which are described via current threats and unknown opportunities:

- Opportunities: any external situation or characteristic along with the demand of the subject in question.

- Threats: challenges resulted from undesirable procedures or external factors which influence the condition of the subject (Eftekhari et al, 2006).

Indeed the key point of this model is the analysis of a range of all situational aspects of the system which provides a useful framework for choosing the approach (Mobaraki, 2007).

Table 2. Matrix table of external factors effective on prioritizing exemplary tourism regions

\begin{tabular}{|c|c|c|}
\hline Variables & Opportunities & Threats \\
\hline Economical & $\begin{array}{l}\text { - Increasing the government's attention to } \\
\text { planning and investment in tourism section } \\
\text { - Increasing the incentive of the free enterprise to } \\
\text { investment in these regions } \\
\text { - Increase in the number of tourists compared to } \\
\text { the past }\end{array}$ & $\begin{array}{l}\text { Increase in the price of land and hence the } \\
\text { increase in the costs of providing tourism } \\
\text { equipment and installations }\end{array}$ \\
\hline $\begin{array}{ll}\begin{array}{l}\text { Social } \\
\text { cultural }\end{array} & \text { and } \\
\end{array}$ & $\begin{array}{l}\text { - Increasing people's motives in order to travel to } \\
\text { these regions }\end{array}$ & $\begin{array}{l}\text { - Increasing facilities and services in } \\
\text { other exemplary regions of the province }\end{array}$ \\
\hline
\end{tabular}




\section{Ml Macrothink}

\begin{tabular}{|c|c|c|}
\hline & $\begin{array}{l}\text { - The possibility of not providing desirable } \\
\text { services and facilities in competing exemplary } \\
\text { regions in the province } \\
\text { - Large population poles near exemplary tourism } \\
\text { regions }\end{array}$ & $\begin{array}{l}\text { - too population density and an increase } \\
\text { in social crimes } \\
\text { - lack of a clear understanding of } \\
\text { tourism on the part of local people of the } \\
\text { regions }\end{array}$ \\
\hline Ecological & $\begin{array}{l}\text { - } \quad \text { adjacency to population centers } \\
\text { - } \quad \text { sustaining the environment and its gaining } \\
\text { importance }\end{array}$ & $\begin{array}{l}\text { - destruction of the environment of the } \\
\text { region } \\
\text { - lack of planning in order to decrease } \\
\text { the environmental effects of tourists }\end{array}$ \\
\hline Organizationa & $\begin{array}{l}\text { - an increase in authorities attention and } \\
\text { willingness in order to develop tourism activities in } \\
\text { these regions }\end{array}$ & $\begin{array}{l}\text { - limited choices of the existing } \\
\text { organizations in order to attract } \\
\text { professionals }\end{array}$ \\
\hline
\end{tabular}

Source: writers Studies

The Table 2 shows external factors affecting tourism priority areas, and has been studied the strengths and weaknesses of economic variables, social, cultural, ecological and institutional systems.SWOT analysis in the form of tables and its steps is done as follows:

1. Making a list of opportunities, threats, strengths and weaknesses in the form of tables

2. Depicting and interpreting each opportunity, threat, strength and weakness in the form of the analysis of the planning of regional and spatial development in SWOT method. (Eftekhari and Mahdavi, 2006). Completing SWOT model and planning various approaches to lead the system will be done in future (Golkar, 2005).

Table 3. Mmatrix table of SWOT and the method of determining strategies

\begin{tabular}{|c|c|c|c|c|}
\hline SWOT matrix & & Strengths & Weaknesses & W \\
\hline Opportunities & $\mathrm{O}$ & Strategy & Strategy & WO \\
\hline Threats & $\mathrm{T}$ & Strategy & Strategy & WT \\
\hline
\end{tabular}

Source: (Eftekhari and Mahdavi, 2006).

The table 3 shows in order to provide strategies and investment policies in exemplary tourism regions, recognition four factors (swot) to eliminate weaknesses, threats, strengths and opportunities for improvement are considered inevitable. Therefore approach the priority areas for investment in the tourism region with list of the most important strengths and opportunities for 1- offer competing/attacking strategies(SO) is based on exploiting the competitive advantages of tourism areas 2- Explain the major opportunities ahead to address weaknesses the revised guidelines review strategy(WO), in order to reallocation of resources 3- Provide examples of the major strengths of exemplary tourism region In order to eliminate threats with emphasis on diversification strategies(ST) 4-Defensive strategies(WT) designed to address the vulnerability of the tourism region.

\subsection{AHP Model}

Analytical hierarchical process (AHP) is a flexible, strong and simple method for deciding in conditions that opposing decision-making standards make it difficult for one to choose between different choices (Bertolini, 2006). This method was suggested for the first time by 


\section{Macrothink}

Thomas Al Saaty in 1980 for expressing multi-measure decisions. Saaty believes that AHP is a technique for complicated decisions in order to decide properly. Therefore AHP helps the programmer choose one of the most appropriate options for eliminating the problems (Saaty, 2008). In AHP method coupled comparison is done between sets for weighting after determining hierarchical levels including purpose, measures, sub-measures and options. While weighting the sets, analysis of the adjustment of judgments is done which must be less than 0.1. after weighting all the measures, sub-measures and options a general comparison of options considering the purpose is done and the result is shown in graphs (Khorshiddust and Aali, 2009). In fact in the process of analysis by AHP model 5 basic st4eps are taken as follows (Azizi and Khalili, 2009):

\subsubsection{Making a Hierarchy}

The process of identifying the elements which leads to making a hierarchical structure is called "making a hierarchy". The structures' being hierarchical is because the elements of decision-making (purpose, measures, sub-measures and options) can be summarized in different levels (Bowen, 1993). Therefore the first step in AHP is making a hierarchical structure of the issues at hand, in which we indicated purposes, measures, sub-measures, options and the relationship among them. The purpose determined in this process is prioritizing the exemplary tourism regions for investment. To achieve this goal, 4 measures are defined: strengths, weaknesses, opportunities and threats. And for each measure some sub-measures are selected as the third level of the hierarchical process. At the fourth level of AHP we have chosen and introduced exemplary tourism regions for Kashan Township. The hierarchical structure of research is shown in figure 1.

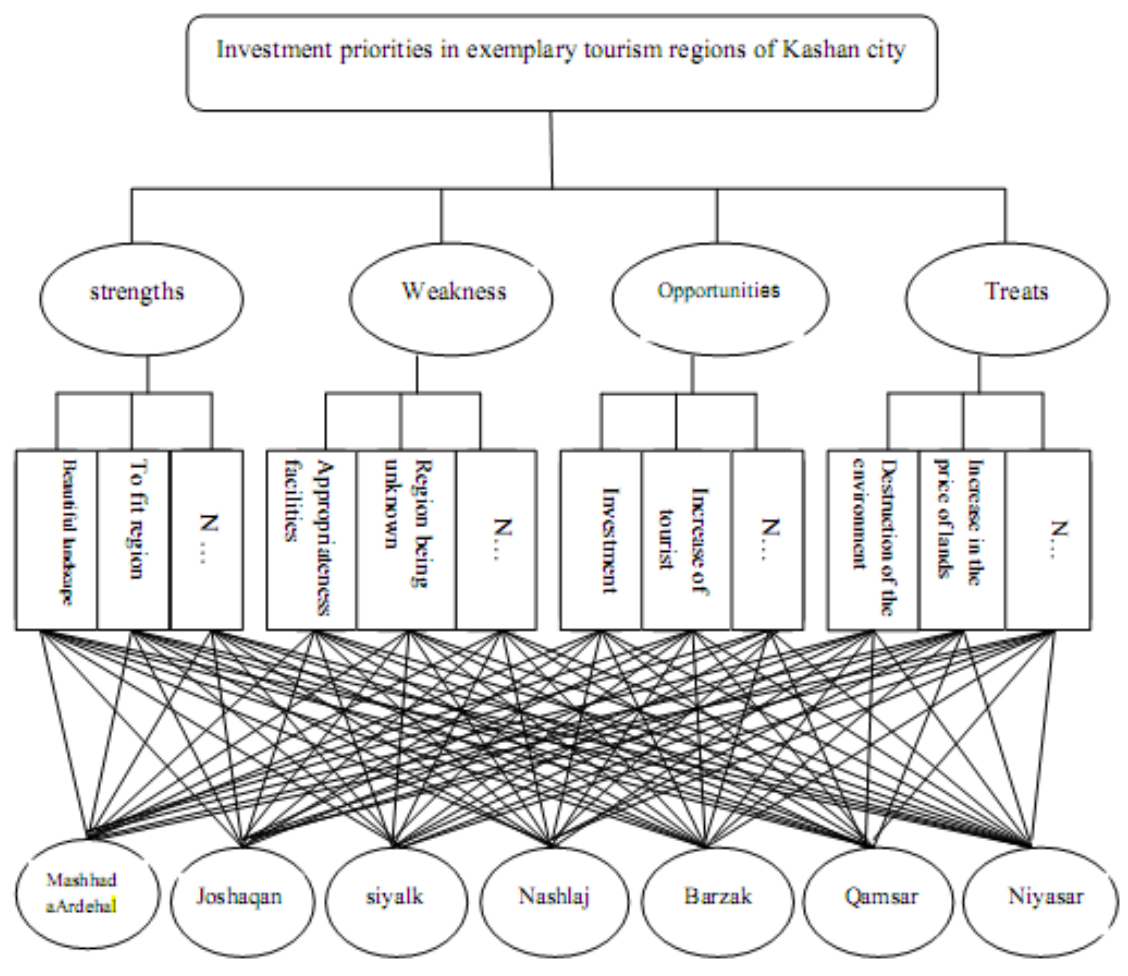

Figure 1. Tree diagram of AHP. Authors, 2013 


\subsubsection{Determining the Importance Coefficient of Measures and Sub-measures}

There are different methods to determine the importance coefficient of measures and sub-measures, the most ordinary of which is binary comparison. In this method measures are compared two by two and the degree of importance of each one is determined in comparison to the other (Bowen, 1990). In this study we have used the standard method (provided by Saaty). We have assigned to each binary comparison a number from 1 to 9 . The meaning of each number is clarified in table 5. After weighting we have normalized the weights. The normalization of weights is achieved by dividing each row of the matrix of binary comparison by the total amount of each column.

Table 4. Saaty's 9-quantity table of proportion for binary comparison

\begin{tabular}{|l|l|}
\hline The proportion of the parameter & Value \\
\hline The importance of the parameter A compared with parameter B & 1 \\
\hline The importance of the parameter A compared with parameter B & 3 \\
\hline The importance of the parameter A compared with parameter B & 5 \\
\hline The importance of the parameter A compared with parameter B & 7 \\
\hline The importance of the parameter A compared with parameter B & 9 \\
\hline Values in between & $2,4,6,8$ \\
\hline
\end{tabular}

Source: (Bowen, 1990)

\subsubsection{Determining the Importance Coefficient of the Options}

After determining the importance coefficient of measures and sub-measures, the importance coefficients of options are determined too. In this step, the priority of each option is judged in relation to measures and if a measure has no sub-measures it is judged directly by the measure itself. The process of calculating the importance coefficient of each option in relation to measures is like determining the importance coefficient in relation to purpose. In both these conditions judgments are made based on binary comparison of measures or options and based on Saaty's 9-quantity scale and thus the matrix of binary comparison of measures or options. From the normalization of the rows of these matrices the intended coefficients are achieved. But we have to consider a major difference in these comparisons. Comparison of different measures is done in relation to measures and sub-measures (if there is no sub-measure), while the comparison of measures is done in relation to the purpose of the study. So in comparison of the options instead of asking 'how much more important is measure $\mathrm{i}$ compared to measure $\mathrm{j}$ in achieving the goal?one should ask 'how much more prioritized is option $\mathrm{i}$ over option $\mathrm{j}$ in relation to sub-measure X?' (Khorshiddust and Aadeli, 2009)

3.2.4. Examining compatibility in judgments: one of the benefits of AHP is determining a possibility of compatibility I judgments made for determining the importance coefficient of measures and sub-measures. The mechanisms for examining compatibility in judgments are calculation of a coefficient named incompatibility ratio (IR) which must be less than 0.1 . Using this coefficient helps in the analysis of decision before the final selection of location (Khorshiddust and Aadeli, 2009). In order to calculate incompatibility ratio, first we 


\section{Ml Macrothink}

multiplied the matrix of coupled comparison (A) by weight (W) in order to gain an appropriate estimation of $\lambda \operatorname{maxW}$. In other words $\mathrm{A} * \mathrm{~W}=\lambda \operatorname{maxW}$. $\Lambda$ max was calculated by dividing $\lambda \max \mathrm{W}$ by $\mathrm{W}$. then we calculated average $\lambda \max$ and incompatibility index from the following equation: (Qodsipour, 2008)

Equation 1:

$$
\begin{array}{r}
C I=\frac{2 \max -n}{\mathrm{n}-1} \\
\text { CR }=\frac{\mathrm{CI}}{\mathrm{RI}}
\end{array}
$$

Equation 2:

In addition, the amount of RI is extracted from the following table:

Table 5. RI amounts of random matrices

\begin{tabular}{|c|c|c|c|c|c|c|c|c|c|c|c|c|c|c|}
\hline 15 & 14 & 13 & 12 & 11 & 10 & 9 & 8 & 7 & 6 & 5 & 4 & 3 & 2 & N \\
\hline 1.59 & 1.57 & 1.56 & 1.48 & 1.51 & 1.49 & 1.45 & 1.41 & 1.32 & 1.24 & 1.12 & .9 & .58 & 0 & R.I \\
\hline
\end{tabular}

If incompatibility is less than or equal to 0.1 the system's compatibility is acceptable; and if it is more than 0.1 the decision-makers ought to reconsider their judgments (Dey and Ramcharan, 2008). The incompatibility ratio of each matrix is mentioned above it.

\section{Research Findings}

Because in AHP the elements of each level are compared to their related element in the higher level in coupled fashion, firstly the weight of measures is determined. These measures are determined with a consideration of the importance of the measures against each other and in relation to the purpose (prioritizing exemplary tourism regions of Kashan Township). In all the tables numbers are shown based on the importance of the measures of the horizontal row compared to the measures of the vertical column. Binary comparison and the importance coefficient of the measures are shown in table 4. Values have been determined according to table 3 .

Table 6. Coupled comparison of measures in order to prioritize investment in exemplary tourism regions of Kashan. Incompatibility 0.00

\begin{tabular}{|l|l|l|l|l|l|}
\hline & Strengths & Weaknesses & Opportunities & Threats & Relative weight \\
\hline Strengths & 1 & 9 & 2 & 9 & 0.53 \\
\hline Weaknesses & -- & 1 & 0.11 & 1 & 0.04 \\
\hline Opportunities & -- & -- & 1 & 9 & 0.37 \\
\hline threats & -- & -- & -- & 1 & 0.04 \\
\hline
\end{tabular}

Considering the fact that each measure consists of some sub-measures with different importance coefficients, after comparing the main measures it comes to sub-measures. In this phase, sub-measures of each measure are compared with one another. So we do a couple $4 \mathrm{~d}$ comparison for sub-measures of each measure (availability, the appropriateness of the region for investment, beautiful scenery, social security, etc.). 


\section{Macrothink}

Environmental Management and Sustainable Development

ISSN 2164-7682

2014, Vol. 3, No. 1

Table 7. Coupled comparison of sub-measures of the measure 'strengths'. Incompatibility 0.04

\begin{tabular}{|c|c|c|c|c|c|c|c|c|c|c|c|}
\hline & $\begin{array}{l}\text { Approp } \\
\text { riatene } \\
\text { ss of } \\
\text { the } \\
\text { region }\end{array}$ & $\begin{array}{l}\text { High } \\
\text { awar } \\
\text { eness }\end{array}$ & artifacts & $\begin{array}{l}\text { Social } \\
\text { securit } \\
\text { y }\end{array}$ & $\begin{array}{l}\text { hospitab } \\
\text { ility }\end{array}$ & $\begin{array}{l}\text { Beautif } \\
\text { ul } \\
\text { scenery }\end{array}$ & $\begin{array}{l}\text { Adjacenc } \\
\text { y to } \\
\text { populatio } \\
\text { n centres }\end{array}$ & $\begin{array}{l}\text { Quiet } \\
\text { environm } \\
\text { ent }\end{array}$ & $\begin{array}{l}\text { availabil } \\
\text { ity }\end{array}$ & $\begin{array}{l}\text { Autho } \\
\text { rities' } \\
\text { belief } \\
\text { in job } \\
\text { creati } \\
\text { on }\end{array}$ & $\begin{array}{l}\text { Rela } \\
\text { tive } \\
\text { wigh } \\
\mathrm{t}\end{array}$ \\
\hline $\begin{array}{l}\text { Appropriateness of } \\
\text { the region }\end{array}$ & 1 & 7 & 6 & 7 & 6 & 2 & 5 & 5 & 5 & 4 & 0.31 \\
\hline High awareness & - & 1 & 0.5 & 1 & 0.5 & 0.16 & 0.33 & 0.33 & 0.5 & 0.33 & 0.03 \\
\hline Artifacts & - & - & 1 & 4 & 4 & 0.25 & 3 & 2 & 2 & 1.5 & 0.10 \\
\hline Social security & - & - & - & 1 & 1 & 0.25 & 1 & 1 & 1 & 0.5 & 0.04 \\
\hline Hospitability & - & - & - & - & 1 & 0.2 & 0.5 & 1 & 0.5 & 0.33 & 0.03 \\
\hline Beautiful scenery & - & - & - & - & - & 1 & 5 & 5 & 5 & 4 & 0.23 \\
\hline $\begin{array}{l}\text { Adjacency to } \\
\text { population centres }\end{array}$ & - & - & - & - & - & - & 1 & 2 & 1 & 1 & 0.06 \\
\hline Quiet environment & - & - & - & - & - & - & - & 1 & 0.5 & 0.33 & 0.04 \\
\hline Availability & - & - & - & - & - & - & - & - & 1 & 0.5 & 0.05 \\
\hline $\begin{array}{l}\text { Authorities' belief } \\
\text { in job creation }\end{array}$ & - & - & - & - & - & - & - & - & - & 1 & 0.08 \\
\hline
\end{tabular}

The table 7 shows, coupled comparison of sub-measures of the measure 'strengths'. The Incompatibility factor table is 0.04 , which is acceptable.

Table 8. Coupled comparison of sub-measures of the measure 'weaknesses'. Incompatibility 0.06

\begin{tabular}{|c|c|c|c|c|c|c|c|c|c|c|}
\hline & $\begin{array}{l}\text { People's } \\
\text { reluctance } \\
\text { to } \\
\text { investmen } \\
\mathrm{t}\end{array}$ & $\begin{array}{l}\text { Inappropr } \\
\text { iateness } \\
\text { of } \\
\text { hygiene } \\
\text { facilities }\end{array}$ & $\begin{array}{l}\text { Inappropria } \\
\text { teness of } \\
\text { residential } \\
\text { facilities }\end{array}$ & $\begin{array}{l}\text { Inappropriate } \\
\text { seasonal } \\
\text { distribution of } \\
\text { tourists }\end{array}$ & $\begin{array}{l}\text { Inappropria } \\
\text { teness of } \\
\text { infrastructu } \\
\text { res }\end{array}$ & $\begin{array}{l}\text { Inappropr } \\
\text { iateness } \\
\text { of } \\
\text { welfare } \\
\text { facilities }\end{array}$ & $\begin{array}{l}\text { Bein } \\
g \\
\text { unkn } \\
\text { own }\end{array}$ & $\begin{array}{l}\text { Unfami } \\
\text { liarity } \\
\text { with } \\
\text { tourism }\end{array}$ & $\begin{array}{l}\text { Disorgan } \\
\text { ization of } \\
\text { the } \\
\text { regions }\end{array}$ & $\begin{array}{l}\text { Rela } \\
\text { tive } \\
\text { weig } \\
\text { ht }\end{array}$ \\
\hline $\begin{array}{l}\text { People's } \\
\text { reluctance to } \\
\text { investment }\end{array}$ & 1 & 2 & 2 & 3 & 5 & 2 & 1 & 0.33 & 4 & 0.15 \\
\hline $\begin{array}{l}\text { Inappropriaten } \\
\text { ess of hygiene } \\
\text { facilities }\end{array}$ & - & 1 & 2 & 2 & 6 & 1 & 1 & 0.25 & 5 & 0.12 \\
\hline $\begin{array}{l}\text { Inappropriaten } \\
\text { ess of } \\
\text { residential } \\
\text { facilities }\end{array}$ & - & - & 1 & 2 & 0.25 & 1 & 0.5 & 0.2 & 2 & 0.08 \\
\hline $\begin{array}{l}\text { Inappropriate } \\
\text { seasonal } \\
\text { distribution of } \\
\text { tourists }\end{array}$ & - & - & - & 1 & 6 & 4 & 2 & 0.5 & 6 & 0.12 \\
\hline
\end{tabular}




\section{Macrothink $\Lambda$ Institute"}

Environmental Management and Sustainable Development

ISSN 2164-7682

2014, Vol. 3, No. 1

\begin{tabular}{|l|l|l|l|l|l|l|l|l|l|}
\hline $\begin{array}{l}\text { Inappropriaten } \\
\text { ess of } \\
\text { infrastructures }\end{array}$ & - & - & - & - & 1 & 0.33 & 0.2 & 0.16 & 0.5 \\
\hline $\begin{array}{l}\text { Inappropriaten } \\
\text { ess of welfare } \\
\text { facilities }\end{array}$ & - & - & - & - & 0.02 \\
\hline $\begin{array}{l}\text { Being } \\
\text { unknown }\end{array}-$ & - & - & - & - & 1 & 0.5 & 0.33 & 1 \\
\hline $\begin{array}{l}\text { Unfamiliarity } \\
\text { with tourism }\end{array}$ & - & - & - & - & - & 1 & 0.5 & 3 \\
\hline $\begin{array}{l}\text { Disorganizatio } \\
\mathrm{n} \text { of the } \\
\text { regions }\end{array}$ & - & - & - & - & - & - & 0.11 \\
\hline
\end{tabular}

The table 8 shows, coupled comparison of sub-measures of the measure 'weaknesses'. The Incompatibility factor table is 0.06 , which is acceptable.

Table 9. Coupled comparison of sub-measures of the measure 'opportunities'. Incompatibility 0.04

\begin{tabular}{|c|c|c|c|c|c|c|c|c|c|c|}
\hline & $\begin{array}{l}\text { Government's } \\
\text { attention to } \\
\text { investment }\end{array}$ & $\begin{array}{l}\text { The } \\
\text { incentive } \\
\text { of the free } \\
\text { enterprise } \\
\text { to } \\
\text { investment }\end{array}$ & $\begin{array}{l}\text { Increase } \\
\text { in the } \\
\text { number } \\
\text { of } \\
\text { tourists }\end{array}$ & $\begin{array}{l}\text { Increase } \\
\text { in } \\
\text { people's } \\
\text { incentive } \\
\text { to travel } \\
\text { in these } \\
\text { regions }\end{array}$ & $\begin{array}{l}\text { Weakness } \\
\text { of } \\
\text { services } \\
\text { in } \\
\text { competing } \\
\text { regions }\end{array}$ & $\begin{array}{l}\text { Large } \\
\text { population } \\
\text { poles }\end{array}$ & $\begin{array}{l}\text { Adjacency } \\
\text { to } \\
\text { population } \\
\text { centres }\end{array}$ & $\begin{array}{l}\text { Importance } \\
\text { of } \\
\text { sustaining } \\
\text { the } \\
\text { environment }\end{array}$ & $\begin{array}{l}\text { Increase in } \\
\text { attending } \\
\text { tourism } \\
\text { development }\end{array}$ & $\begin{array}{l}\text { Relative } \\
\text { weight }\end{array}$ \\
\hline $\begin{array}{l}\text { Government's } \\
\text { attention to } \\
\text { investment }\end{array}$ & 1 & 1 & 2 & 2 & 4 & 5 & 5 & 3 & 1 & 0.19 \\
\hline $\begin{array}{l}\text { The incentive } \\
\text { of the free } \\
\text { enterprise to } \\
\text { investment }\end{array}$ & - & 1 & 2 & 2 & 4 & 5 & 5 & 3 & 1 & 0.19 \\
\hline $\begin{array}{l}\text { Increase in } \\
\text { the number of } \\
\text { tourists }\end{array}$ & - & - & 1 & 2 & 2 & 4 & 5 & 5 & 0.25 & 0.13 \\
\hline $\begin{array}{l}\text { Increase in } \\
\text { people's } \\
\text { incentive to } \\
\text { travel in these } \\
\text { regions } \\
\end{array}$ & - & - & - & 1 & 2 & 3 & 3 & 4 & 0.33 & 0.09 \\
\hline $\begin{array}{l}\text { Weakness of } \\
\text { services in } \\
\text { competing } \\
\text { regions }\end{array}$ & - & - & - & - & 1 & 1 & 1 & 2 & 0.33 & 0.05 \\
\hline $\begin{array}{l}\text { Large } \\
\text { population } \\
\text { poles }\end{array}$ & - & - & - & - & - & 1 & 1 & 2 & 0.33 & 0.04 \\
\hline $\begin{array}{l}\text { Adjacency to } \\
\text { population } \\
\text { centres }\end{array}$ & - & - & - & - & - & - & 1 & 2 & 0.25 & 0.04 \\
\hline $\begin{array}{l}\text { Importance of } \\
\text { sustaining the } \\
\text { environment }\end{array}$ & - & - & - & - & - & - & - & 1 & 0.25 & 0.03 \\
\hline $\begin{array}{l}\text { Increase in } \\
\text { attending } \\
\text { tourism } \\
\text { development }\end{array}$ & - & - & - & - & - & - & - & - & 1 & 0.21 \\
\hline
\end{tabular}

The table 9 shows, coupled comparison of sub-measures of the measure 'opportunities'. The Incompatibility factor table is 0.04 , which is acceptable. 


\section{Macrothink}

Environmental Management and Sustainable Development

ISSN 2164-7682

2014, Vol. 3, No. 1

Table 10. Coupled comparison of sub-measures of the measure 'threats'. Incompatibility 0.04

\begin{tabular}{|c|c|c|c|c|c|c|c|c|}
\hline & $\begin{array}{l}\text { Increa } \\
\text { se in } \\
\text { the } \\
\text { price } \\
\text { of } \\
\text { land }\end{array}$ & $\begin{array}{l}\text { Increase } \\
\text { in the } \\
\text { competito } \\
\text { rs' welfare } \\
\text { services }\end{array}$ & $\begin{array}{l}\text { Increase } \\
\text { in social } \\
\text { offences }\end{array}$ & $\begin{array}{l}\text { Murky } \\
\text { understan } \\
\text { ding of } \\
\text { tourism }\end{array}$ & $\begin{array}{l}\text { Destruction } \\
\text { of the } \\
\text { environment }\end{array}$ & $\begin{array}{l}\text { Lack of } \\
\text { planning for } \\
\text { reducing } \\
\text { environment } \\
\text { al damages }\end{array}$ & $\begin{array}{l}\text { Limited } \\
\text { choices of } \\
\text { related } \\
\text { organizatio } \\
\text { ns }\end{array}$ & $\begin{array}{l}\text { Relati } \\
\text { ve } \\
\text { weigh } \\
t\end{array}$ \\
\hline $\begin{array}{l}\text { Increase in } \\
\text { the price of } \\
\text { land }\end{array}$ & 1 & 0.33 & 0.25 & 0.2 & 2 & 2 & 0.33 & 0.06 \\
\hline $\begin{array}{l}\text { Increase in } \\
\text { the } \\
\text { competitors' } \\
\text { welfare } \\
\text { services } \\
\end{array}$ & - & 1 & 0.5 & 0.25 & 3 & 3 & 0.33 & 0.11 \\
\hline $\begin{array}{ll}\text { Increase in } \\
\text { social } \\
\text { offences }\end{array}$ & - & - & 1 & 0.33 & 4 & 4 & 0.33 & 0.16 \\
\hline $\begin{array}{l}\text { Murky } \\
\text { understandin } \\
\mathrm{g} \text { of tourism }\end{array}$ & - & - & - & 1 & 5 & 5 & 1 & 0.30 \\
\hline $\begin{array}{l}\text { Destruction } \\
\text { of the } \\
\text { environment }\end{array}$ & - & - & - & - & 1 & 1 & 0.25 & 0.04 \\
\hline $\begin{array}{l}\text { Lack of } \\
\text { planning for } \\
\text { reducing } \\
\text { environmenta } \\
1 \text { damages }\end{array}$ & - & - & - & - & - & 1 & 0.25 & 0.04 \\
\hline $\begin{array}{l}\text { Limited } \\
\text { choices of } \\
\text { related } \\
\text { organizations }\end{array}$ & & - & - & - & - & - & 1 & 0.26 \\
\hline
\end{tabular}

The table 10 shows, coupled comparison of sub-measures of the measure 'threats'. The Incompatibility factor table is 0.04 , which is acceptable.

In the last stage of prioritizing exemplary tourism regions of Kashan Township, after weighting and coupled comparison of measures and sub-measures, we determined the importance coefficients of options (exemplary tourism regions) and compared them based on the selected measures. It is noteworthy that if the selected measures in the research have no sub-measures we judge the options directly by the measure. After coupled comparison of options on the basis of measures and sub-measures we have determined the final score and priority of the selected options by combining the importance coefficients $f$ the options in relation to each measure and sub-measure. In order to prevent the text from becoming too long, we have included only a summary of tables with final results. The numerical coefficients in table 12 are achieved from coupled comparison of options in relation to each sub-measure calculated by Expert Choice software. Weight (Wj) in table 12 is the main weight of each sub-measure of the study calculated from multiplying the weight of measures by each sub-measure. Table 13 shows the priority coefficient for each option. In table 14 the selected options have been prioritized based on the priority coefficient for each one. 


\section{Macrothink}

Environmental Management and Sustainable Development

ISSN 2164-7682

2014, Vol. 3, No. 1

Table 11. Matrices weight of options of the study calculated for matrices to weight options on the basis sub- measure

\begin{tabular}{|c|c|c|c|c|c|c|c|c|c|c|c|c|c|c|c|c|c|c|}
\hline $\mathrm{W}_{\mathrm{j}}$ & .001 & & 07 & .07 & .04 & .03 & .01 & .01 & .01 & .01 & .002 & .004 & .006 & .01 & .001 & .001 & .01 & \\
\hline & $\begin{array}{l}\overrightarrow{0} \\
\vec{\Rightarrow}\end{array}$ & 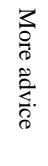 & 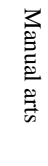 & 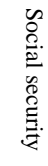 & 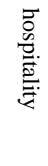 & 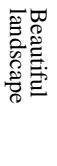 & 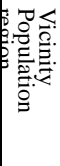 & 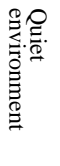 & 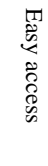 & 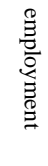 & 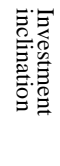 & 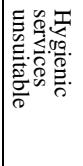 & 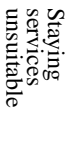 & 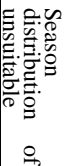 & 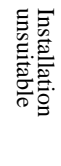 & 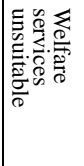 & 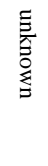 & 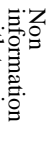 \\
\hline niyasar & .29 & .29 & .17 & .29 & .29 & .11 & .23 & .22 & .16 & .22 & .22 & .16 & .3 & .11 & .16 & .23 & .22 & .11 \\
\hline Qamsar & .23 & .11 & .29 & .13 & .23 & .29 & .17 & .16 & .11 & .3 & .3 & .3 & .22 & .3 & .3 & .17 & .16 & .22 \\
\hline Barzak & .17 & .07 & .23 & .08 & .17 & .23 & .08 & .3 & .08 & .11 & .16 & .22 & .16 & .05 & .22 & .08 & .08 & .16 \\
\hline Nashlaj & .04 & .05 & .06 & .04 & .04 & .08 & .04 & .11 & .05 & .04 & .04 & .05 & .04 & .04 & .04 & .04 & .04 & .08 \\
\hline Siyalk & .05 & .23 & .11 & .22 & .11 & .05 & .11 & .05 & .22 & .08 & .08 & .04 & .08 & .22 & .08 & .11 & .11 & .05 \\
\hline Joshagan & .07 & .04 & .04 & .05 & .05 & .17 & .05 & .08 & .04 & .05 & .05 & .11 & .05 & .08 & .05 & .05 & .05 & .3 \\
\hline Mashhad ardahal & .11 & .17 & .07 & .16 & .08 & .04 & .29 & .04 & .3 & .16 & .11 & .08 & .12 & .16 & .12 & .29 & .3 & .04 \\
\hline$W_{j}$ & .16 & .01 & .05 & .02 & .01 & .1 & .03 & .02 & .02 & .04 & .006 & .004 & .003 & .004 & .008 & .002 & .04 & .01 \\
\hline
\end{tabular}

\begin{tabular}{|c|c|c|c|c|c|c|c|c|c|c|c|c|c|c|c|c|}
\hline & 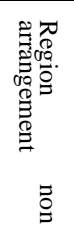 & 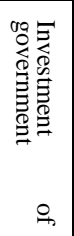 & 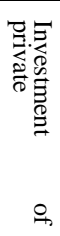 & 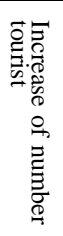 & 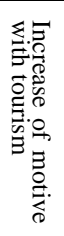 & 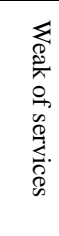 & 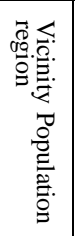 & 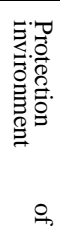 & 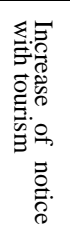 & 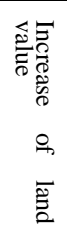 & 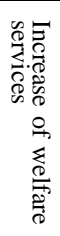 & 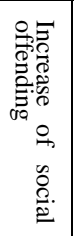 & 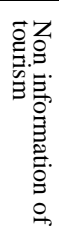 & 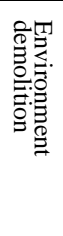 & 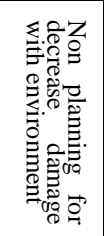 & 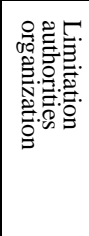 \\
\hline niyasar & .16 & .22 & .22 & .3 & .3 & .3 & .3 & .17 & .22 & .23 & .16 & .16 & .17 & .05 & .05 & .22 \\
\hline Qamsar & .3 & .3 & .16 & .22 & .16 & .16 & .16 & .29 & .16 & .17 & .3 & .11 & .29 & .08 & .08 & .16 \\
\hline Barzak & .22 & .16 & .11 & .16 & .11 & .11 & .11 & .23 & .08 & .08 & .22 & .08 & .23 & .17 & .17 & .11 \\
\hline Nashlaj & .05 & .05 & .05 & .05 & .04 & .05 & .05 & .06 & .04 & .04 & .04 & .05 & .06 & .22 & .22 & .05 \\
\hline Siyalk & .04 & .11 & .08 & .08 & .08 & .08 & .08 & .11 & .11 & .11 & .05 & .22 & .11 & .11 & .11 & .3 \\
\hline Joshagan & .11 & .04 & .04 & .04 & .05 & .04 & .04 & .04 & .05 & .05 & .08 & .04 & .04 & .3 & .3 & .04 \\
\hline Mashhad ardahal & .06 & .08 & .3 & .12 & .22 & .22 & .22 & .07 & .3 & .29 & .12 & .3 & .07 & .04 & .04 & .05 \\
\hline
\end{tabular}

Table 12. He prioritizing coefficients of exemplary tourism regions of Kashan Township for investment

\begin{tabular}{|c|c|c|c|c|c|c|c|}
\hline Name & $\begin{array}{l}\text { Niyasar } \\
\text { region }\end{array}$ & $\begin{array}{l}\text { Qamsar } \\
\text { region }\end{array}$ & $\begin{array}{l}\text { Barzak } \\
\text { region }\end{array}$ & $\begin{array}{l}\text { Nashlaj } \\
\text { region }\end{array}$ & $\begin{array}{l}\text { Siyalk } \\
\text { region }\end{array}$ & $\begin{array}{l}\text { Joshaqan } \\
\text { region }\end{array}$ & $\begin{array}{l}\text { Mashhad Ardehal } \\
\text { region }\end{array}$ \\
\hline coefficient & 1.7157 & 1.7384 & 0.9062 & 0.1928 & 0.6261 & 0.4089 & 1.2071 \\
\hline
\end{tabular}

Table 13. Prioritizing exemplary tourism regions of Kashan Township for investment

\begin{tabular}{|l|l|l|l|l|l|l|l|}
\hline Priority & First & Second & Third & Forth & Fifth & Sixth & Seventh \\
\hline Region & Qamsar & Niyasar & Mashhad Ardehal & Barzak & Siyalk & Joshaqan & Nashlaj \\
\hline Priority coefficient & 1.7384 & 1.7157 & 1.2071 & 0.9062 & 0.6261 & 0.4089 & 0.1928 \\
\hline
\end{tabular}

As indicated in tables 12 and 13, Qamsar region with the priority coefficient of 1.7384 is the best locus for investments of tourism development among exemplary tourism regions of Kashan Township. The results of the priorities are shown in figure 2. 


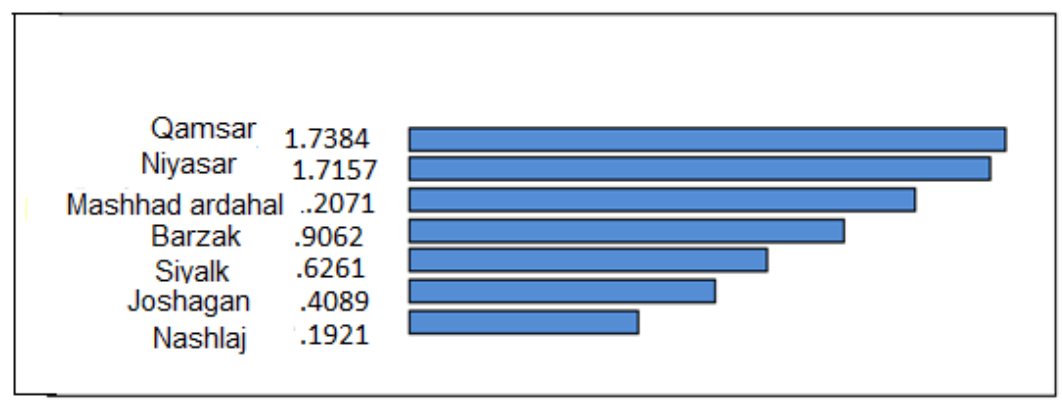

Figure 2. Priority diagram of exemplary tourism regions of Kashan Township using Expert Choice software

\section{Discussion and Conclusion}

The topic of exemplary tourism regions was introduced for the first time in article 8 of the act of establishment of the cultural heritage and tourism organization in acted in 2003 with the motive of making suitable and equipped space for tourists in order to provide the grounds of constant development of cultural heritage, artifacts and tourism, and attracting domestic and foreign investors to produce infrastructural establishments in order to better introduce historical monuments and spaces, Iranism and tourism, and providing proper services for tourists (cultural heritage, artifacts and tourism organization in Kerman province, 2010). So in this research Kashan township has been selected for assessment and determining investment priorities in exemplary tourism regions and is assessed by means of SWOT strategic model, hierarchical analysis and Expert Choice software. AHP is one of multi-measure decision-making methods. In conditions that Multiple and contrastive variables make decision-making process difficult, AHP is used For reasonable decision-making. This method is based upon coupled comparison of the factors and allows the managers and decision-makers to examine different scenarios. It also makes possible the formulation of the problem in a hierarchical manner and considering different qualitative and quantitative measures. AHP includes different options in decision-making and allows for the analysis of sensitivity about measures and sub-measures. Furthermore, it facilitates judgments and calculations and indicates the extent of compatibility and incompatibility of the final decision. In this research after determining the strengths, weaknesses, threats and opportunities of tourism development in exemplary tourism regions of Kashan township using SWOT model and selecting the, as measures and sub-measures of selecting the appropriate exemplary tourism region for investment, exemplary tourism regions of Kashan township were determined as options under investigation. After weighting steps in Expert Choice software, the options in question were examined based on the selected measures and sub-measures, and finally Qamsar exemplary region gained the highest scores with a priority coefficient of 1.7384 among the exemplary regions of Kashan Township. Thus, it has the best conditions for investment and civil campaigns. Finally we provide strategies for developing these regions and other selected regions and for purposeful investments in these regions and constant development of tourism considering strengths, weaknesses, opportunities and threats.

Table 14. Competing/attacking strategies 


\begin{tabular}{|l|l|}
\hline Row & competing/attacking strategies(SO) \\
\hline 1 & $\begin{array}{l}\text { Purposeful benefiting from an increase in travelling incentive among urban class and adjacency to } \\
\text { population centers in order to benefit from the tourism potentials of the region to create job and } \\
\text { income for local dwellers }\end{array}$ \\
\hline 2 & Knowing and benefiting from tourism attractions of exemplary tourism regions \\
\hline 3 & $\begin{array}{l}\text { Coordination among organizations and offices related to the projects of exemplary regions in order to } \\
\text { unify operations in the field of tourism }\end{array}$ \\
\hline 4 & $\begin{array}{l}\text { Advertising, paving the way and creating incentives in the free enterprise in order to invest in } \\
\text { exemplary tourism regions }\end{array}$ \\
\hline 5 & $\begin{array}{l}\text { Concentration of acidities and investments of tourism in order to better benefit from attractions and } \\
\text { unusual tourism resources of exemplary tourism regions }\end{array}$ \\
\hline 6 & $\begin{array}{l}\text { Increasing security for tourists via communication and security bases and temporary units in } \\
\text { exemplary regions }\end{array}$ \\
\hline
\end{tabular}

The table 14 shows, attacking strategies in exemplary tourism regions, that The result is that the strengths and opportunities

\section{Table 15. Variety strategies (ST)}

\begin{tabular}{|l|l|}
\hline Row & variety strategies(ST) \\
\hline 1 & $\begin{array}{l}\text { Serious and constant observation of related organizations in order to prevent the destruction of the } \\
\text { environment }\end{array}$ \\
\hline 2 & $\begin{array}{l}\text { Training and creating a culture among local dwellers of the exemplary tourism regions about tourism } \\
\text { and tourists }\end{array}$ \\
\hline 3 & $\begin{array}{l}\text { Variation in tourism facilities and services in exemplary tourism regions in order to satisfy tourists } \\
\text { and increase the competitive strength with other exemplary regions in attracting tourists }\end{array}$ \\
\hline 4 & $\begin{array}{l}\text { Increasing the capacity and determining the extent of desirability in order to decrease the pressure on } \\
\text { the environment and prevent density and overuse of the strengths of the region }\end{array}$ \\
\hline 5 & Tourism plans for exemplary regions of the city and turning them into tourism poles in the province \\
\hline 6 & Recruiting and using professional people in the field of tourism \\
\hline
\end{tabular}

The table 15 shows, variety strategies in exemplary tourism regions, that the result is that the strength and opportunities.

Table 16. Review strategies (WO)

\begin{tabular}{|l|l|}
\hline Row & review strategies (WO) \\
\hline 1 & $\begin{array}{l}\text { Strengthening exemplary regions and paying attention to infrastructures and infrastructural facilities } \\
\text { for the welfare of tourists, particularly hygiene, health care and transportation facilities }\end{array}$ \\
\hline 2 & $\begin{array}{l}\text { Review in people's participation and maximizing people's jobs in the field of tourism in exemplary } \\
\text { regions through proper training of the people in order to take part in tourism }\end{array}$ \\
\hline 3 & $\begin{array}{l}\text { Using controls in order to sustain the environment and historical monuments in exemplary regions } \\
\text { and providing different services in the field of tourism }\end{array}$ \\
\hline 5 & $\begin{array}{l}\text { Review in the method of selecting exemplary tourism regions in order to reduce costs and constantly } \\
\text { develop tourism }\end{array}$ \\
\hline 6 & $\begin{array}{l}\text { Review in the method of providing and distinguishing lands in exemplary regions with an emphasis } \\
\text { on avoiding a change in implementations of natural resources in order to sustain the environment }\end{array}$ \\
\hline
\end{tabular}

The table 16 shows, review strategies in exemplary tourism regions, that the result is that the weak and opportunities

Table 17. Defensive strategies (WT)

Row 1 defensive strategies (WT) 


\begin{tabular}{|l|l|}
\hline 1 & $\begin{array}{l}\text { Holding seminars and meetings(investment in exemplary tourism regions) with the cooperation of } \\
\text { different organizations }\end{array}$ \\
\hline 2 & $\begin{array}{l}\text { Grounding and persuading local people in order to develop tourism infrastructures, equipments and } \\
\text { facilities }\end{array}$ \\
\hline 3 & $\begin{array}{l}\text { Preventing chaos in construction particularly in the field of natural and historical scenery with cultural } \\
\text { and tourism value }\end{array}$ \\
\hline 4 & Developing facilities and infrastructures necessary for exemplary tourism regions \\
\hline 5 & $\begin{array}{l}\text { Training and informing people about facing tourists in order to avoid opposition between tourists and } \\
\text { local people }\end{array}$ \\
\hline 6 & $\begin{array}{l}\text { Holding training classes in order to increase the level of vocational expertise of the staff related to } \\
\text { tourism }\end{array}$ \\
\hline
\end{tabular}

The table 17 shows, defensive strategies in exemplary tourism regions, that the result is that the weak and treats.

\section{References}

Azizi, M., \& Khalili, A. (2009). Measurement of Skeleton Patterning of Rural Textures in Directing Projects Based on AHP. Human Geography Researches, 67, 27-40.

Bertolini. M, M, Braglia. (2006). Application of the AHP Methodology in Making a Proposal for a Public Work Contract. Management, 2, 422-430.

Bowen .W. M. (1990). Subjective judgments and Data Environment Analysis in Site Selection Computer. Environment and Urban Systems, 14, 133-144. http://dx.doi.org/10.1016/0198-9715(90)90018-O

Bowen, William. M. (1993). AHP: Multiple Criteria Evaluation, in Klosterman R.et al, Spreadsheet models for urban and regional analysis, New Brunswick: center for urban policy Research, 112.

Cultural Heritage, Artifacts and Tourism Organization, Kerman Province. (2010). Opportunities of Tourism Investment, Kerman Province.

Daniel, S., Geoff, M. B., \& Michael, S. (2004). Climate change and the distribution of climatic resources for tourism in North America, department of geography, university of waterloo,200 university avenue west, waterloo, Ontario N2L 3G1, Canada.vol.27,105-117.

Dey, P. K., \& Ramcharan, E. K. (2008). Analytic hierarchy process helps select site for limestone quarry explosion in Barbados. Journal of Environmental management, 88, 138-139. http://dx.doi.org/10.1016/j.jenvman.2007.07.011

Ebrahimzadeh, I., \& Aqasizadeh, A. ( 2009). Analysis of the Factors Effective on the Development of Tourism in Chabahar Coastal Region Using SWOT Model. Urban and Regional Studies and Researches, first year, number 1, summer. 108.

Eftekhar, R., \& Mahdavi, A. (2006). Approaches to Develop Rural Tourism (Case Study: the Small Lavasan) Using SWOT Model. Modares Magazine, Tarbiat Modares University Press, number $45,87$. 


\section{Macrothink}

Environmental Management and Sustainable Development

ISSN 2164-7682 2014, Vol. 3, No. 1

Fanni, Z., \& Mohammadnejhad, A. (2010). The Role of Urban Management in Tourism Development (Case Study: Ramsar City), Tourism Information Magazine, numbers 11 and 12, summer, 102.

Farajzadeh, M. (2005). Geographical Information System and its Application in Tourism Planning. SAMT Press.42.

Golkar, K. (2005). Making SWOT Analytical Technique Appropriate for Utilizing in Urban Planning. Soffeh Magazine, 41, 49.

Hekmatnia, H., \& Musavi, M. (2006). The Application of Model in Geography (Urban and Regional Planning), Elme Novin Press.293

Khatayi, M et. Al. (2008). Measuring the Applications of the Hotels of Tehran Using Covering Analysis of Data. Economic Researches Quarterly, $8^{\text {th }}$ year, summer, 3.

Khorshiddust, A., \& Adeli, Z. (2009). Using AHP for fimding Optimal Locus for Burying Refuse (Case Study: Bonab Town). Ecology Magazine, $35^{\text {th }}$ year, number 50, summer 2009, 27-32.

Manley, C. (1990). What is tourism, the journal of tourism studies, Vol11, N1. 50.

Mobaraki, O. (2007). Spatial Planning of Malekan City. MA Thesis in Geography and Urban Planning. Advisor: Beyk Mohammadi, PhD. Isfahan University, 199.

Momeni, M, et. Al. (1999). Structure and Application of Religious and Cultural Tourism and the Prominence of Integrat6ive Management in Mashhad Metropolis. Geography and Development Magazine. $6^{\text {th }}$ year, number 11, 15.

Papoli, Y. M., \& Saqayi, M. (1999). Tourism, Nature and Concepts, Tehran University Press. 10

Qodsipour, H. (2008). The Analytical Hierarchical Press. Tehran. Amirkabir University Press.

Saaty, T. L. (2006). Relative Measurement and its Generalization in Decision Making: Why Pair wise Comparisons are Central in Mathematics for the Measurement of Intangible Factors-The Analytic Hierarchy/Net work Process, 102, 251-318.

World Tourism Organization. (2000). Tourism Planning at Rational and Regional Level, Translated by Ranjbarian, B and Zahedi, M. University Uprising, Isfahan University.13

\section{Copyright Disclaimer}

Copyright reserved by the author(s).

This article is an open-access article distributed under the terms and conditions of the Creative Commons Attribution license (http://creativecommons.org/licenses/by/3.0/). 